\title{
Campus of Vienna University of Economics and Business
}

\author{
Jindřrich Svatoš \\ Department of Architecture, Czech Technical University in Prague, Czech Republic
}

Submission: September 01, 2020; Published: September 16, 2020

*Corresponding author: Jindřich Svatoš, Department of Architecture, Czech Technical University in Prague, Czech Republic

\begin{abstract}
Vienna University of Economics (WU), which is one of the largest universities in Europe, currently has about 23,000 students and approximately 1,500 teachers. WU has opened a new campus in 2013. Studio which was selected for the development of the site plan was chosen on the basis of the competition for Austrian and German architects in 2007. The following year, an international competition was announced for individual buildings of the campus. What does the realization of this plan looks like? Was it possible to build this campus quite near the center of Vienna? Where does this incredible number of students fit? How do they live and study there? Is it possible for a total of six teams of architects from around the world to design a campus of the future together? What is the transport solution for such a complex? How to study and how to live in the space created like this? What is the public space of this campus about? These and other questions will be answered from the architect's point of view as well as from the perspective as an ordinary visitor of this interesting area.
\end{abstract}

Keywords: Campus; Public space; Competition; Architecture

\section{Term Campus}

Campus (an English word, from Latin campus, a field, an exercise area) is a contiguous university compound, particularly in the British and the American context.

A university campus is comprised of green spaces (parks, playing fields), and of buildings containing lecture halls and laboratories, libraries, study rooms and dormitories. An area of a typical campus can consist of several hectares and it is usually located on the outskirts of a city, alternatively even outside of a city. Restaurants, stores and similar amenities can be found on the campus 'edges. The main advantage of a campus is the concentration of teaching, learning, and living in one place, plus a separation from the city life, something that encourages students to focus on studies and scientific research. On the other hand, the disconnection from the city and its cultural life can be a definite disadvantage [1].

\section{First Impression}

I have come accidentally across an article in Domus magazine, about the newly opened campus of the Vienna University of Economics and. I could not stop wondering!! Well, somebody was showing off! It can't be possible. What kind of buildings are they? I thought for myself - again some horror and then stopped paying any attention to this project. After several months, during one of my visits to Vienna, I have told myself that I should have a look at this, up to then, by me denounced collection of buildings.

After entering the campus, which is located relatively close to the city center, and after a gradual walk around this compound, my initial opinion of individual buildings did not change. However, the longer I stayed on the campus, around which I walked in its entirety, and after I followed movements of students, I comprehended everything that this public space offers and realized various options how it can be utilized. After that I had to give up and change my initial opinion, and in contrast to pay homage to the contracting authority. I had to acknowledge the positive outcome of both architectural competitions and to praise the urban design solution for the entire campus of the Vienna University of Economics.

\section{Introduction}

The campus of the Vienna University of Economics represents a city development of the $21^{\text {st }}$ century. The university precinct that woke Vienna up. I quote Stanislav Komárek, who described the former Habsburg metropolis as "a perfectly embalmed remnant of a former cultural glory". Some of the inhabitants of Vienna also spoke of the insignificance of their city, of hopeless provincialism [2]. However, everything is now being forgotten and the Austrian 


\section{Civil Engineering Research Journal}

metropolis is becoming a dynamically developing city. The city is rated as one amongst those with the best quality of life in Europe. The face of Vienna is changing. I mention for example 220 meters high skyscraper from architect Perrault and the new Vienna Main Station. The campus of the future, the Vienna University of Economics, belongs here too [3].

\section{Architectural Competitions}

The Vienna University of Economics was founded in 1898. It is one of the largest schools of economics in Europe. Several times during its existence the university has strived to provide appropriate new buildings, however due to the reason of continuous growth of the student population these buildings became unsatisfactory. A plot of land, which was to be found near the center of Vienna, located to the north east of St. Stephen's Cathedral was eventually selected for the new campus (Figure 1). The size of the site area is 600 meters x 200 meters, and it lies next door to the Prater and the exhibition grounds. The highly positive aspect of the selected site is the fact that it is located between two metro stations.

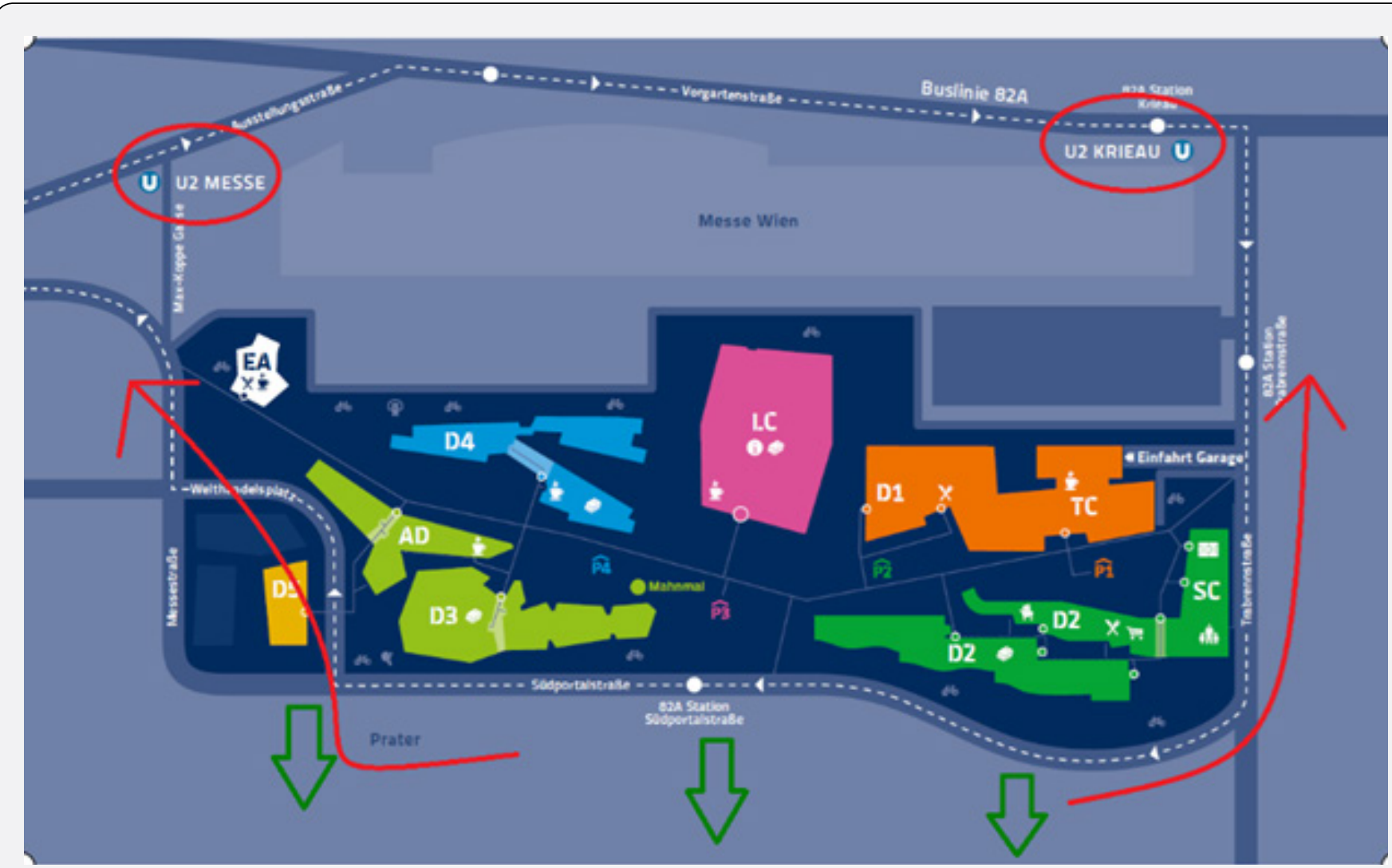

Figure 1: Site Plan of the campus (Source: Vienna University of Economicsand Business, Available from: www.wu.ac.at).

Two architectural competitions for the new campus of the University of Economics were initiated. The first one, for the master plan, was open only to Austrian and German architects. That competition took place in 2007 and was focused not only on the urban and architectural design, but interestingly, a comprehensive transformation of the university and its public image was called for.

The competition's conditions envisioned an open campus full of creative atmosphere, both the campus and its buildings were to promote economic, ecological and social sustainability. A campus that will be a true part of the city even outside of the school hours [4]. The jury selected the design by Austrian BUSarchitektur out of twenty-four competition entries. BUSarchitektur described their solution for the WU campus as a set of buildings within in a park, the buildings which look via numerous openings into the neighboring Prater, spaces to be discovered and explored by visitors.

The main axis of the complex, in the east west direction, is in its footprint slightly curved, with the peak of the curve directed towards the south, and which is then, in appropriate places, divided up by dormitories. A green living oasis is created first, then followed by a relaxation zone with a wooden terrace and a café, while the exhibition space is conceived as an inhabitable garden. (Figure 2) The subsequent second competition was intended for invited architectural offices only. More specifically, it was a competition to design individual campus buildings. By the end of 2008 everything was clear. The winning schemes were submitted by studios from Austria, Great Britain, Spain and a team 


\section{Civil Engineering Research Journal}

that was American/Japanese. The grouping of six buildings shape the resulting form of the campus. The winning masterplan for the whole area bears the main share of the successful proposal, although each of the six buildings is completely different [5].

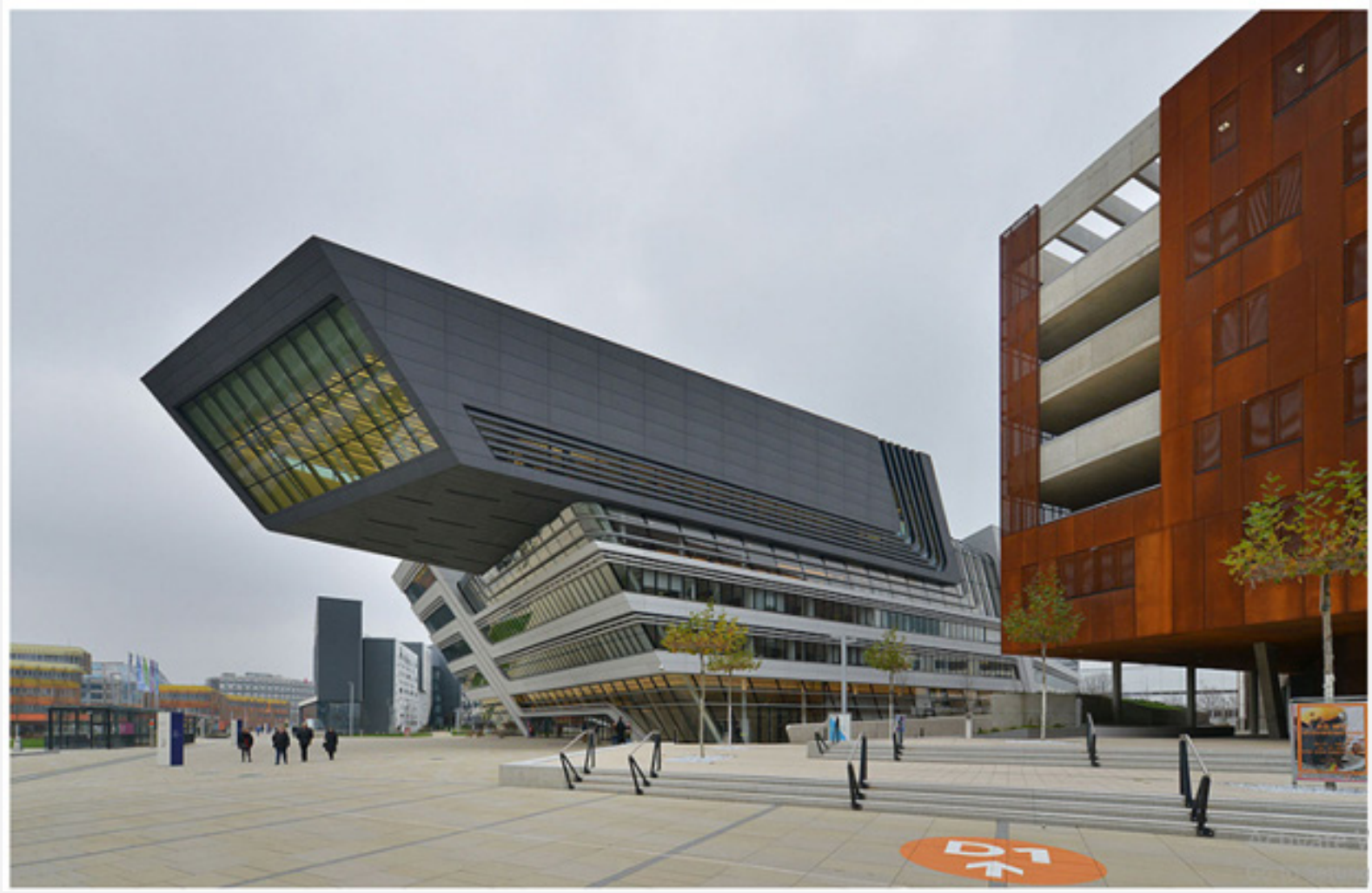

Figure 2: Library and study center, author's photo archive \& D1 Learning center and Student dining, author's photo archive.

\section{The Campus}

The library building with study spaces is set in the center of the campus. This building is not intended for teaching, it does not serve only students, it also serves the wider public. And conferences are held here. The building offers all latest technological advancements and conveniences necessary for the given functions. The library's advantage is that from several indoor spaces designed for studying, one can look out into the surroundings, into the greenery. Visitors are thus still "connected" to daylight and weather. There is a large gathering area in front of the library designed for holding of various university events, especially music events and programs.

The already mentioned axis of the complex is formed by a wide pedestrian road, to which campus buildings are individually connected, including the library with the study center, the chancellor's office, dormitories, teaching spaces, the dining hall, cafes, restaurants, and various amenities. On ground floors of all buildings one can find cafes, even a bakery shop. There are also two restaurants, a large grocery store and all basic facilities serving those who live here. All conveniences are then made complete by the kindergarten serving students with children.
The solution of transport situation puts the campus into a superb position. The area is accessible from the north by the metro by the U2 line from the two metro stations: Messe-Prater and Krieau. The metro is supplemented by a bus route encircling the compound, connecting the campus to the two metro stations. Private cars park in an underground carpark or in the parking garage located in the eastern quarter of the campus.

One could say that the campus is formed by a collection of architecturally diverse buildings. Each one has its own distinctive character; however, the greatest attribute of the complex is the master plan and implementation of it. Pedestrian areas, the greenery, outdoor lighting, relaxation and assembly amenities, gardens, the information system, outdoor seating, connection to transportation and to the surrounding parks are exemplary. Last but not least, the campus is a publicly accessible space. The is a possibility for the public to enter the campus and by its movement to further animate the entire place throughout the whole day. The public access is not in any way restricted, there are no gatehouses, fencing or checkpoints. The area is open 24 hours a day and is from time to time patrolled by the campus security guards. 


\section{Civil Engineering Research Journal}

The outdoor lighting designed for the campus area is very pleasing. The light intensity is higher in places of greater movement of students and visitors, on the contrary is used sparingly but sufficiently, in places of resting and the greenery. For example, not all walking routes are fully illuminated, but the less frequented ones utilize lighting from main routes. The secondary routes are bright enough, as they do not need the full light intensity and that way also remain kind to the greenery at night.

By applying the $21^{\text {st }}$ century technologies and by using geothermal heat and rainwater the university contributes to the environmental protection. All campus buildings are designed to be energy efficient. Fifty percent of heating energy is sourced from geothermal plants. And rainwater is collected from all open outdoor areas and is then used for watering of plants and sanitary facilities. [4] The size of this Viennese campus is comparable to the complex of buildings at the VSB-TU Ostrava as well as to the extent of buildings at the CTU in Prague. Interestingly, the longitudinal axes of the three above mentioned premises are identical in their lengths.

\section{Conclusion}

The Campus of the Vienna University of Economics does not represent an outburst of architectural realizations. It is a place for studying, lodging and for spending leisure time as per the $21^{\text {st }}$ century expectations. I believe that many universities, not only European ones, would welcome a similar facility, especially its valuable public spaces.

This university compound has become the new architectural symbol of the city. The campus opened in 2013. It consists of 6 buildings, currently accommodating 23,600 students, 2,100 teachers and the university staff. The construction period extended over 41 months. The cost of construction can be compared to the cost of constructing 13 football stadiums in the Czech Republic at that same time. The authors of the master plan: BUSarchitektur, Vienna, Austria. The authors of individual buildings:

D1 Teaching Center - BUSarchitektur/ Spinadel. Bolivar, Pflügel /, Vienna.

D2 Departments and Student Center / Hitoshi Abe /, Sendai and Los Angeles.

D3 Departments and Administration / Sir Peter Cook and CRABstudio /, London.

D4 Departments / Estudio Carme Pinós/, Barcelona Executive Academy / NO.MAD, Arquitectos /, Madrid.

The Library and the Learning Center/ Zaha Hadid Architects /, Hamburg

Investment: €492 million

Areas: 99,000 sqm of usable area

35,000 sqm of built-up area

55,000 sqm of public access areas [6].

\section{References}

1. Wikipedia [online] Available from: www.cs.wikipedia.org/wiki [vid. July 7,2019$]$.

2. (2014) Hospodáŕské noviny, Vikend [online] Available from: www. ihned.cz [vid June 6, 2019].

3. City One [online] Available from: www.cityone.cz [vid] June 25, 2019].

4. Archiweb [online] Available from: www.archiweb.cz [vid. June 14, 2019].

5. Domus [online] Available from: www.domus.com [vid. May 30, 2019].

6. Vienna Universityof Economics and Business [online] Available from: www.wu.ac.at, www.executiveacademy.at [vid, June25, 2019].

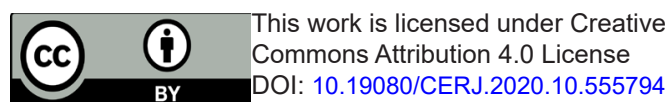

\begin{tabular}{l} 
Your next submission with Juniper Publishers \\
will reach you the below assets \\
- Quality Editorial service \\
- Swift Peer Review \\
- Reprints availability \\
- E-prints Service \\
- Manuscript Podcast for convenient understanding \\
- Global attainment for your research \\
- Manuscript accessibility in different formats \\
( Pdf, E-pub, Full Text, Audio) \\
- Unceasing customer service \\
Track the below URL for one-step submission \\
https://juniperpublishers.com/online-submission.php \\
\hline
\end{tabular}

